\title{
ステンレス鋼実機圧延に適用しうる 表面光沢推定システムの提案
}

\author{
小豆島 明* \\ Proposal of Estimation System for Surface Brightness of Rolled Sheet \\ in Stainless Steel Cold Rolling Process
}

Akira Azushima

Synopsis : In the previous paper, the author has reported that the surface brightness is expressed as three functions of the inlet oil film thickness and the surface brightnesses of roll and sheet before rolling, and a system for estimating and controlling the surface brightness before rolling can be constructed by using this relation. In this paper, a new system for estimating the surface brightness after each pass in actual mill for cold rolling of stainless steel is proposed by developing this relation. In the new system, the estimation is carried out as follows: (1) Preparation of as hot rolled specimen, (2) Input of rolling conditions at each pass in actual mill, ( 3 ) Calculation of the inlet oil film thickness at each pass, (4) Determination of rolling conditions at each pass in laboratory mill, (5) Rolling in laboratory mill and measurement of surface properties of rolled specimen, (6) Surface brightness after final pass.

By using the new estimating system, the surface properties after each pass are measured and it is seen that the system is able to estimate the surface brightness after each pass in actual mill.

Key words : stainless steel ; cold rolling ; surface qualities ; surface brightness ; surface roughness ; inlet oil film thickness.

\section{1. 緒言}

現在，ステンレス鋼板の冷間圧延においては，優れた表 面光沢を得るために低粘度鉱油べースのニート形を用いて， 小径ロールあるいは低圧延速度で圧延が行われている。し かし, 生産性向上のために圧延速度の増加やロール径の大 きな圧延機の使用の試みがなされているが，その場合製品 の表面光沢が低下寸る問題に直面している。そのため圧延 後の材料の表面性状を定量的に把握し, 圧下率, 圧延速度, 圧延油粘度及びロール・材料の表面粗さなどのトライボロ ジー因子により精度よく，厳重に管理することが望まれて いる。

著者らは，この観点から冷間圧延後の表面性状に及ぼす トライボロジー因子の影響を定量的に調べるため, 圧下率, 圧延速度及びロール・材料の表面粗さを広範囲, 系統的に 変化させて圧延を行い, 圧延後の表面性状を測定し, 表面 推定・管理のための系統的なデータ収集を行った。そして, これらのデータベースの中の表面光沢とレイノルズ方程式 より計算した入口油膜厚みとの関係から, 圧延後の材料の 表面光沢を推定・管理しうる新ななシステムの構築が可能 なことを示した。1)

本研究は, 以上の著者の研究をべースにし，ステンレス 鋼板の冷間圧延における実機の各パス後の表面光沢を推定
するためのシステムを新たに提案し，この推定システムの 実機への適用について検討し，更に高表面光沢創製の可能 性についても検討したものである。

\section{2. 表面光沢推定システムの構築}

ステンレス鋼の冷間圧延におけるニート潤滑の場合，圧 延後の材料の表面光沢 $G_{s}$ は加工因子 (ロール速度 $V_{r}$, 材料 の入口速度 $V_{1}$, 入口板厚 $t_{1}$, 圧下率 $r$, ロール半径 $R$, 変形 抵抗 $k)$, 潤滑油因子 (常温・常圧の粘度 $\eta_{0}$, 圧力係数 $\alpha$, 温 度係数 $\beta)$ 及び圧延前のロールと材料の表面粗さ $\left(R_{a_{0}}{ }^{R O L L}\right.$, $\left.R_{a_{0}}{ }^{M A T E}\right)$ などに影響を受けることが知られている(1) 7)。その 結果から, 圧延後の材料の表面光沢 $G_{s}$ は加工因子, 潤滑油 因子を従属変数として,

$$
\begin{aligned}
& G_{s}=G_{s}\left(V_{r}, V_{1}, t_{1}, \quad r, R, k, \eta_{0}, \alpha, \beta, R_{a_{0}}^{R O L L}\right. \text {, } \\
& R_{a_{0}}{ }^{M A T E} \text {, etc) }
\end{aligned}
$$

で表すことができる。しかし，前報1において，各種圧延条 件により圧延後の材料の表面光沢の実験データをレイノル ズ方程式から計算した入口油膜厚みでプロットすると，圧 延後の材料の表面光沢は

$$
G_{s}=G_{s}\left(h_{1}, R_{a_{0}}{ }^{R O L L}, R_{a_{0}}{ }^{M A T E}\right)
$$


のように表すことができることを示した。

(2) 式の関係が完全に定量的に示されるならば，各パス の圧延条件から圧延前に圧延後の材料の表面光沢を定量的 に推定することができる。しかし，現状では実際に適用し うる ( 2 ) 式の定量的な関係が明らかでないので，実機に適 用しうる別のシステムを構築しなければならない。

(2) 式は, 圧延後の材料の表面光沢が圧延前のロール及 び材料の表面粗さ並びにレイノルズ方程式から計算される 入口油膜厚みで与えられることを示している。更に，その 関係式は (2) 式が全ての条件で定量的に明らかでなくても， 実験室レベルでの低速度の圧延機を用いることにより，実 機における圧延後の製品の表面光沢が推定可能なことを示 している。その方法とは，まず実際の同じ圧延材料を用意 し, 圧延前のロール表面粗さを実機における $R_{a_{0}}{ }^{R O L L}$ 一致 させ，つづいて実機の圧延条件から計算される入口油膜厚 み $h_{1}$ と同じ值になるように実験室用圧延機の圧延条件を設定 して圧延する方法である。その方法により実機の圧延後の 表面光沢と一致する表面を実験室用圧延機によって圧延す ることが可能となる。この方法の推定システムの流れ困を Fig. 1 に示す。その内容は以下の通りである。

( I ) 実機で冷間圧延するために使用するものと同じ材料を 用意する。

(II) 実機の各パスにおける圧延条件(入口板厚 $t_{1}$, ロール半 径 $R$, ロール速度 $V_{r}$, 材料の入口速度 $V_{1}$, 圧下率 $r$, 後 方張力 $T_{b}$, 圧延油の粘度 $\eta$, 圧延油粘度の圧力係数及び 温度係数 $\alpha, \beta$, ロールの表面粗さ $R_{a_{0}}{ }^{R O L L}$, 材料及び口 一ルの表面温度 $T_{M A T E}, T_{R O L L}$ など)のデータを調べる。

(III) 各パスにおける入口油膜厚み $h_{1}$ を熱的効果を考慮したレ イノルズ方程式を用いて計算する。

(IV) 実験室用圧延機において，(III）で計算された各パスの

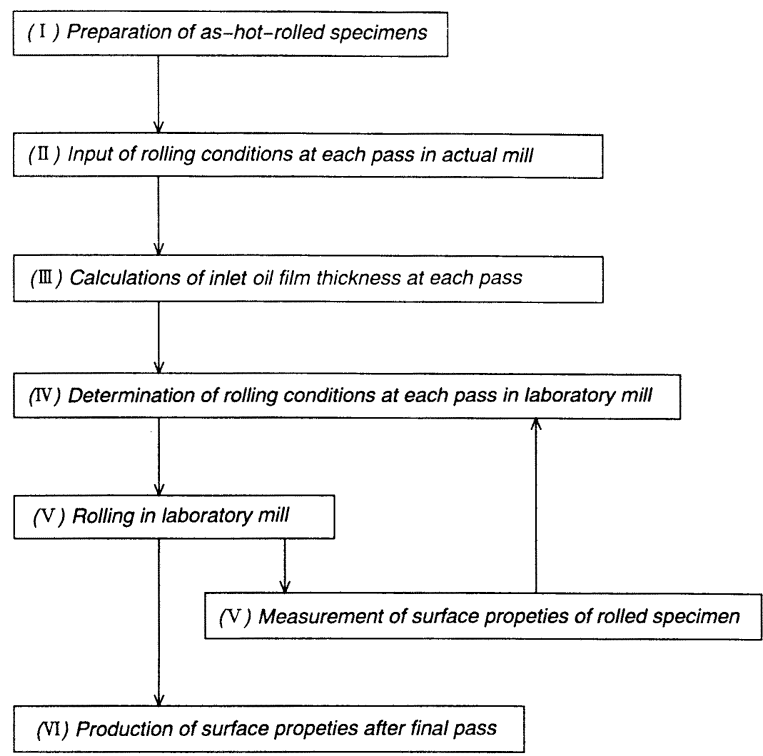

Fig. 1. Flow chart of estimation system for surface brightness of rolled sheet.
入口油膜厚み $h_{1}$ に一致する圧延条件を設定し(例えば, 圧延速度，圧延油の粘度などを調整することにより入 口油膜厚みを一致させる), 各パスの実験室用圧延機の ロールの表面粗さを実機のロールの表面粗さに一致さ せる。

( V ) (IV)の圧延条件で圧延し, 各パス圧延後の材料の表面 性状を測定する。

(IV) 最終パス後の材料の表面が実機で圧延を行った製品表 面となる。

\section{3. 推定システムの適用}

\section{$3 \cdot 1$ 実機の圧延条件}

ステンレス鋼板の多くの冷間圧延は，七ンジミャ一圧延 機を用いて二ート潤滑による多パス圧延が行われている。 そのため, 今回の表面光沢推定システムを適用する圧延条 件としては，その実機の最も一般的であると思われる各パ スの圧延条件を取り上げた。その圧延条件をTable 1 に示す。 圧延のワークロール径は $\phi 60 \mathrm{~mm} て ゙$, 圧延材料は初期板厚 4.0 mmのSUS430フェライト系ステンレス鋼である。圧延は 8 パスで行われ，圧延油は粘度 $10 \mathrm{cSt}\left(40^{\circ} \mathrm{C}\right)$ の鉱油ベースで ある。

\section{$3 \cdot 2$ 各パスにおける入口油膜厚みの計算}

Fig. 2 は, ロールと材料間で流体潤滑されている入口部の 模式困を示す。入口油膜厚みの計算のための仮定及び式の 導出の詳細については著者らの文献89)で説明してあるので ここでは省略する。入口油膜厚み $h_{1}$ の計算に必要なレイノル ズ方程式, エネルギー式, 粘度式はFig. 2 より

$$
\begin{aligned}
& \frac{d p}{d x}=-\frac{6 \eta\left(V_{r}+V_{1}\right)}{\tan \theta}\left(\frac{h-h_{1}}{h^{3}}\right) \\
& K \frac{\partial^{2} T}{\partial y^{2}}+\eta\left(\frac{\partial u}{\partial y}\right)^{2}=0 \cdots \cdots \cdots \cdots \\
& \eta=\eta_{0} \exp \left\{\alpha p-\beta\left(T_{0}-T\right)\right\} \ldots . . .
\end{aligned}
$$

Table 1. Pass schedule on a practical mill with $60 \mathrm{~mm}$ diameter work rolls using a lubricant (mineral oil) with a viscosity of $10 \mathrm{cSt}$ $\left(40^{\circ} \mathrm{C}\right)$.

\begin{tabular}{c|c|c}
\hline Pass No. & Thickness $(\mathrm{mm})$ & Rolling speed $(\mathrm{m} / \mathrm{min})$ \\
\hline 0 & 4.0 & \\
\hline 1 & 3.5 & 100 \\
\hline 2 & 2.9 & 100 \\
\hline 3 & 2.4 & 100 \\
\hline 4 & 1.9 & 200 \\
\hline 5 & 1.5 & 200 \\
\hline 6 & 1.2 & 200 \\
\hline 7 & 1.0 & 200 \\
\hline 8 & 0.8 & 200 \\
\hline
\end{tabular}




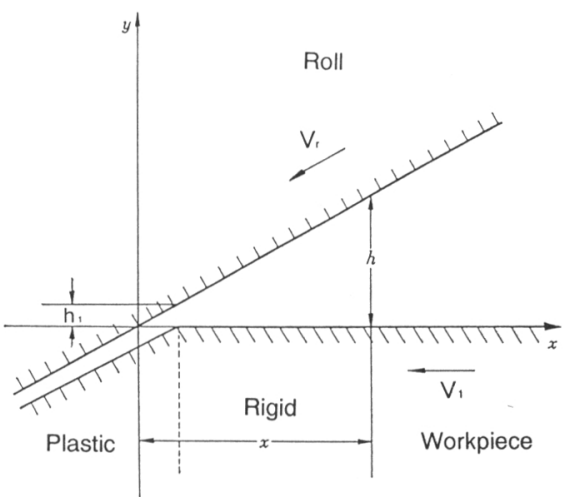

Fig. 2. Schematic representation of inlet zone between roll and workpiece.

を用いた。ここで, pは圧力, $h$ は油膜厚み, $\theta$ はかみ込み角, $T$ は温度， $T_{0}$ は圧延油の温度，Kは圧延油の熱伝導率であ る。

（３）式を計算する境界条件としては，後方張力が無い場 合

$$
\begin{array}{lll}
h=100 \times h_{1} & \text { のとき } & p=p^{*} \\
h=h_{1} & \text { のとき } & p=\sigma_{0}
\end{array}
$$

とした。ここで, $p^{*}$ は油膜厚みが入口油膜厚みの 100 倍にな れば熱的効果の影響を無視してよいとして，（3)式から求 めた圧力であり，原は材料の降伏応力である。次に，(4)式 の圧延油の速度 $u$ は, 次式

$$
u=\left\{V_{r}+\left(V_{1}-V_{r}\right) \frac{h-y}{h}\right\}+\left\{-\frac{y(h-y)}{2 \eta} \frac{d p}{d x}\right\}
$$

を用いた。(4)式の温度の境界条件としては

$$
\begin{array}{lll}
y=0 & \text { のをき } & T=T_{M A T E} \\
y=h & \text { のとき } & T=T_{R O L L}
\end{array}
$$

とし，(4)式の積分を行い油膜断面の平均温度 $T_{m}$ を求めた。 入口油膜厚2の計算方法は, 入口油膜厚み $h_{1}$ 娄仮定して, 初期值を求め, 圧力及び温度をRunge-Kutta法及びNewton

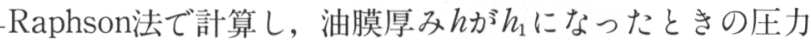
$p$ が材料の降伏応力 $\sigma_{0} に$ 等しいかぼうか比較して, $p=\sigma_{0} に$ なるまで $h_{1}$ の変更を行い, 入口油膜厚及を決定するものであ る。後方張力が作用する場合には, 入口点での圧力 $p$ t材料 が塑性変形する降伏条件を満足するようにしなければなら ない。この方法を用いて, Table 1 の各パスでの入口油膜厚 みの計算を行った。

\section{$3 \cdot 3$ 実験室用圧延機}

推定システムのための圧延実験には, Fig. 3 に示す広範囲 速度可変実験室用圧延機10)を用いた。その圧延機の上下ロー

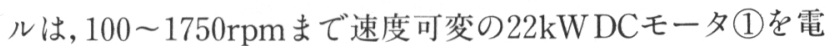
磁クラッチ(2)を通して回転するか，4～40rpmまで速度可変 のACモータ(3)をカップリング(4)を通して回転させるかであ

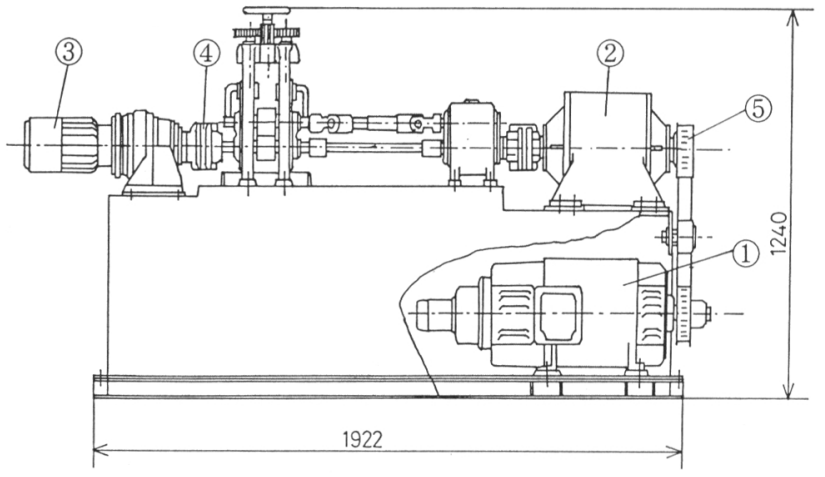

Fig. 3. Outside drawing of the laboratory mill with $76 \mathrm{~mm}$ diameter work roll with a wide range of rolling speed $(\sim 420 \mathrm{~m} / \mathrm{min})$. (1) $22 \mathrm{~kW}$ DC motor, (2) magnetic clutch, (3) AC motor, (4) coupling, (5) timing belt.

る。DCモータの回転は, タイミングベルト (5)によ上下ロ 一ルに伝えられ，それぞれの軸に取り付けられた歯車によ り回転比を $1 ： 1 ， 2 ： 1$ 及び $3 ： 1$ に変化することがで きる。現在この圧延機は $2: 1$ として, (1) と(3)の二つのモ 一夕を用いることにより上下ロール回転数を 4 ～875 rpmま で連続的に変化できるようにしてある。圧延機は 2 段で，

上下ロールはSUJ- 2 製の径 $76 \mathrm{~mm}$, 胴長 $60 \mathrm{~mm}$ である。

\section{$3 \cdot 4$ 実験室用圧延機の圧延条件と実験方法}

実験に用いた材料は, 板厚 $3.12 \mathrm{~mm}$ のSUS430フェライト 系ステンレス鋼熱延板である。その表面の顕微鏡写真をFig. 4 に示す。この原板は実機の冷間圧延のために使用されて いる材料である。実験室用圧延機のロール表面は, 実験 [ I ] においてはロール表面をスムースとし，\#1500エメリ紙で

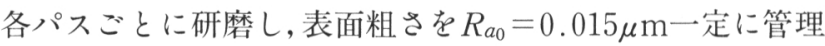
した。

実験 [II］においては，実機の各パスでのロール表面粗 さにできるだけ一致させるように 1,2 パスでは\# 120 エメ リ紙，3，4パスでは２40エメリ紙，5，6パスでは\#400 エメリ紙及び $7 ， 8$ パスでは＃1500エメリ紙でロール表面 を研磨した。それぞれのパスにおけるロールの表面加工条 件及び表面粗さをTable 2 に示す。

Table 1 の実機のパススケジュールにおける各パスで計算 した入口油膜厚みに一致させる実験室用圧延機における圧 延条件をTable 2 に示す。この実験に用いた圧延油はパラフ

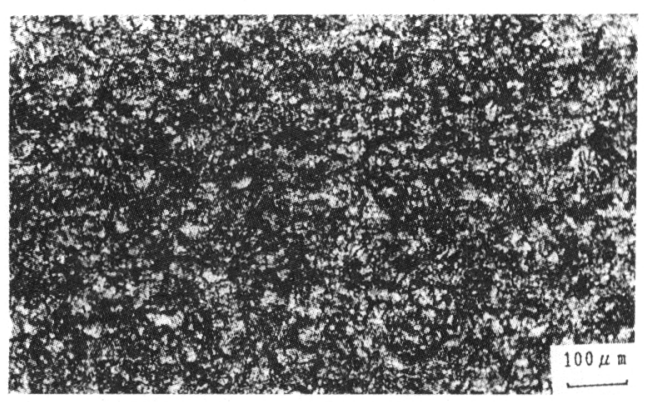

Fig. 4. Surface photograph of as-hot-rolled strip. 
Table 2. Pass schedule and roll surface in experiment [II] on a laboratory mill with $76 \mathrm{~mm}$ diameter work rolls using a lubricant (paraffinic base oil) witha viscosity of $340 \mathrm{cSt}$ $\left(20^{\circ} \mathrm{C}\right)$.

\begin{tabular}{c|c|c|c|c}
\hline \multirow{2}{*}{$\begin{array}{c}\text { Pass } \\
\text { No. }\end{array}$} & $\begin{array}{c}\text { Reduction } \\
(\%)\end{array}$ & $\begin{array}{c}\text { Rolling } \\
\text { speed } \\
(\mathrm{rpm})\end{array}$ & \multicolumn{2}{|c}{ Roll surface in experiment [II] } \\
\cline { 5 - 6 } & 13 & 17 & 120 & 0.40 \\
\hline 1 & 13 & 17 & 120 & 0.40 \\
\hline 2 & 13 & 17 & 240 & 0.14 \\
\hline 3 & 17 & 33 & 240 & 0.14 \\
\hline 4 & 18 & 33 & 400 & 0.045 \\
\hline 5 & 18 & 33 & 400 & 0.045 \\
\hline 6 & 17 & 33 & 1500 & 0.015 \\
\hline 7 & 17 & 33 & 1500 & 0.015 \\
\hline 8 & & & & \\
\hline
\end{tabular}

イン系鉱油で，その粘度は $340 \mathrm{cSt}\left(20^{\circ} \mathrm{C}\right)$ である。圧延は室 温 $\left(20^{\circ} \mathrm{C}\right)$ で行った。

実験室用圧延機の各パスの圧延は，実機にできるだけ一 致させたTable 2 に示すパススケジュールで行った。庄延油 はニートでロール全面に塗布し，圧延試験片はぼぶ付けに した。最初の圧延試験片の寸法は, 幅 $22 \mathrm{~mm}$, 長さ $250 \mathrm{~mm}$ であった。本実験では，圧延試験片を多数用意し，各パス 終了ごとにそれまでのパススケジュールで圧延された試験 片居 2 本以上保存した。各パス後の材料表面は, 光沢計に より幅方向の $G_{S}(20)$ を，触針式表面粗さ計により幅方向の 表面粗さ $R_{a}$ を測定し，金属顕微鏡により表面写真を撮影し た。

\section{$3 \cdot 5$ 推定システムによる圧延後の表面性状}

Fig. 5 及びFig. 6 に実験 $[\mathrm{I}]$ 及び実験 $[\mathrm{II}]$ の各パス圧 延後の材料表面の表面光沢 $G_{s}$ と表面粗さ $R_{a}$ を示し, Fig. 7 に金属顕微鏡写真を示す。

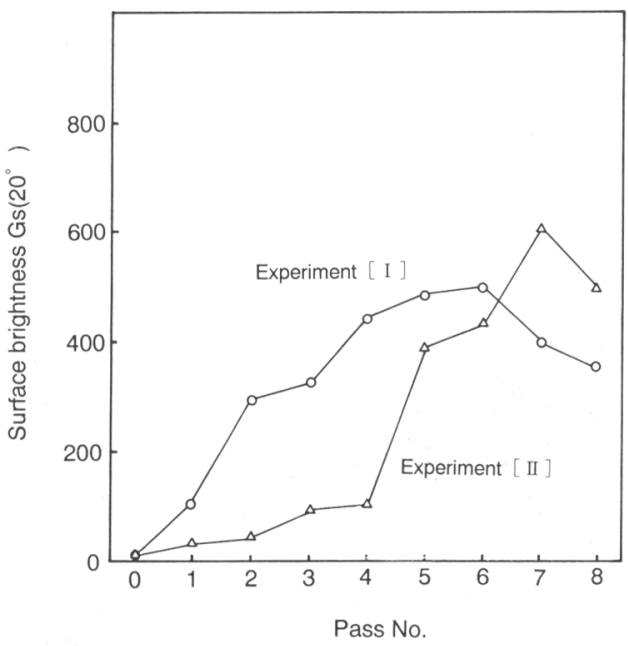

Fig. 5. Surface brightness $G_{s}$ (20) of rolled sheets at each pass schedule in experiments [I ] and [II ].

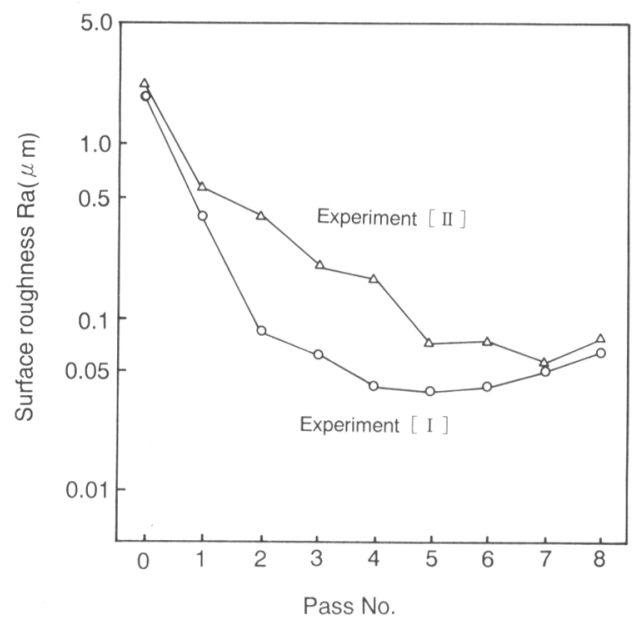

Fig. 6. Surface roughness of rolled sheets at each pass schedule in experiments [I] and [II].

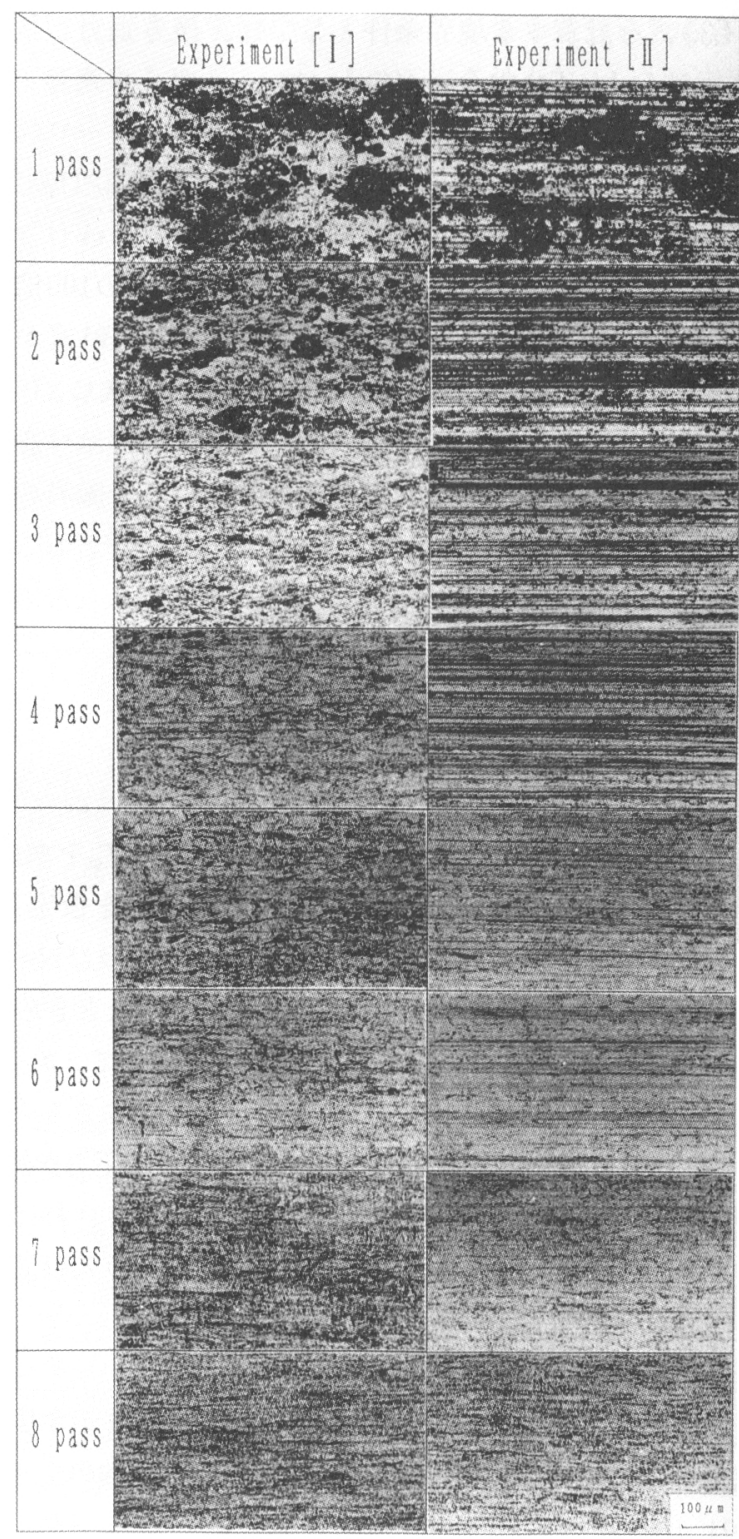

Fig. 7. Surface photographs of sheet rolled at each pass schedule in experiments [ I ] and [II]. 
実験 $[\mathrm{I}$ ］の表面光沢は 6 パス目までは上昇し，500を越 える值にまで達しているが，その後の $7 ， 8$ パスになると 低下している。同じ実験の表面粗さは，表面光沢とは異な り5パス目までは低下しているが，その後のパスでは増加 している。一方, 実験 [II ] の表面光沢はロール表面粗さ が大きい 4 パス目までは100以上と非常に低く，ロール表面 粗さが小さくなった 5 パス及び 7 パス目でそれぞれ大きな 增加が得られている。しかし，8パス目では表面光沢は低 下してしまった。同じ実験の表面粗さは，ロール表面粗さ の変化と対応して 7 パス目まで低下しているが， 8 パス目 だけが前のパスと比べ増加した。

次に, 実験 $[\mathrm{I}]$ と実験 [II ] の結果を比較すると,Fig. 5 においてロール表面粗さを変化させた実験 [II] の方が 7 及び 8 パスにおける表面光沢が高くなっている。しかし， Fig. 6 から 7 及び 8 パスでの表面粗さが実験 [II]の方が低 くなってはいない。このことは，大きな表面凹凸のある熱 延板を多パス圧延して，材料表面を鏡面化していく過程に おいて，それぞれの各パスでのロール表面を最適に管理す る必要のあることが理解できる。そのことは, Fig. 7 の実験 [I ] と実験 [II ] の各パス後の材料表面の顕微鏡写真を 比較すればよく理解できる。初期のパスでは，圧延油がト ラップされて生じる材料表面凹部をできるだけ圧延変形に より除去することが望ましい。そのためには，実験［II］ のような大きな圧延方向の規則的な凹凸をロール表面につ ける方が好ましいことがわかる11。

最終パスにおいて優れた表面光沢を得るためには，鋼板 の材料表面の性状が重要なことがFig. 7 の表面写真から理解 しうる。即ち, 実験 $[\mathrm{I}],[\mathrm{II}]$ の 7 及び 8 パスにおいて は両方とも同じ表面粗さをもつロールを使用したにもかか わらず，実験 [II] の表面光沢が高くなっている。これは， 6 パス終了後の表面写真を見ると実験［I］ではランダム なオイルピット凹部が多数散在しているのに対し, 実験 $[$ II $]$ では規則的なロール研磨による軽度のスジが観察される。 この差が7パス後の表面光沢の差に大きな影響を与えたこ とになる。そこで，次にこの 7 パス圧延の際の差を更に定 量的に理解するための検討を行った。

\section{4. 本システムを用いたフパス压延の際の表面光 沢に及ぼす材料表面性状の影響の検討}

前章において表面光沢推定システムの適用について検討 を行った際，ロールの表面粗さの差によって多パス圧延後 の材料の表面光沢に大きな差を生じることが理解できた。 特に, 7 パス圧延の際の差を定量的に理解して，高表面光 沢創製の可能性についての検討を行うことが必要であるこ とがわかった。

本実験においては 7 パス压延の際の表面光沢に及ぼす材 料表面性状の影響を定量的に調べため，本システムを用
Table 3. Properties of rolling specimens. The specimens from No.2 to No.8 were rolled with work rolls having various surface roughnesses and the specimens from No.9 to No. 12 were deformed up to various strain stages by tensile test.

\begin{tabular}{c|c|c|c|c}
\hline $\begin{array}{c}\text { Sample } \\
\text { No. }\end{array}$ & $\begin{array}{c}\text { Thickness } \\
(\mathrm{mm})\end{array}$ & $\begin{array}{c}\text { Surface } \\
\text { roughness } \\
R_{a}(\mu \mathrm{m})\end{array}$ & $\begin{array}{c}\text { Appendix } \\
\text { Nory paper }\end{array}$ & $\begin{array}{c}\text { Tensile } \\
\text { strain }\end{array}$ \\
\hline 1 & 0.770 & 0.029 & & \\
\hline 2 & 0.705 & 0.038 & $\# 1000$ & \\
\hline 3 & 0.705 & 0.045 & $\# 600$ & \\
\hline 4 & 0.705 & 0.048 & $\# 500$ & \\
\hline 5 & 0.705 & 0.079 & $\# 400$ & \\
\hline 6 & 0.705 & 0.106 & $\# 320$ & $19 \%$ \\
\hline 7 & 0.705 & 0.12 & $\# 240$ & $10 \%$ \\
\hline 8 & 0.705 & 0.45 & $\# 120$ & \\
\hline 9 & 0.763 & 0.40 & & \\
\hline 10 & 0.745 & 0.70 & & \\
\hline 11 & 0.720 & 1.46 & & \\
\hline 12 & 0.705 & 2.33 & & $15 \%$ \\
\hline
\end{tabular}

いて，表面性状（表面粗さ，表面形態）の異なる材料を鏡 面のロールを用いて圧延した後の材料表面の測定を行った。

\section{$4 \cdot 1$ 実験方法}

圧延試験材料は, 板圧 $0.77 \mathrm{~mm}$ のブライト面をもつSUS430 フェライト系ステンレス鋼を母材とし，種々の表面粗さを もつロールで圧下率 $8 \%$ のドライ圧延により規則的な凹凸 をつけたもの（No.2 No. 8$)$ 及び数段階のひずみまでの 引張変形によりランダムな凹凸をつけたもの（No. 9 No. 12）を用意した。

それぞれの圧延試験片の性状をTable 3 に示す。No. 1 8 のドライ圧延の際のロールはTable 3 に示すエメリ研磨紙で 研磨し, No. 9 12は引張ひずみを 5〜19\%与えたものであ る。

ロール表面は\#1500エメリ紙で研磨し表面粗さを0.015 $\mu \mathrm{m} R_{a}$ 一定に管理した。圧延は, Table 1 の実機の 7 パスと 同じ圧延条件を推定し，圧延速度33rpm，圧下率 $20 \%$ とした。 圧延油は, 粘度は $340 \mathrm{cSt}\left(20^{\circ} \mathrm{C}\right)$ のパラフィン系鉱油を用い, ニート潤滑で圧延した。圧延は室温 $\left(20^{\circ} \mathrm{C}\right)$ で行った。圧 延後，材料表面は光沢計により $G_{s}(20)$ を，触針式表面粗さ 計により表面粗さ $R_{a}$ を, 金属顕微鏡により表面写真を測定 及び撮影した。

\section{$4 \cdot 2$ 実験結果及び考察}

Fig. 8 に種々の表面性状をもつ圧延試験片の圧延前後の表 面光沢の変化を示す。No. 9 12のランダムな表面凹凸をも つ圧延試験片の場合, 圧延後の表面光沢はNo.1の試験片の 值を越えることはなく，圧延前の表面粗さが低くなるに伴 い，表面光沢は増加している。これは，圧延後の表面写真 から，圧延前の表面粗さが大きいほどオイルピット量が多 


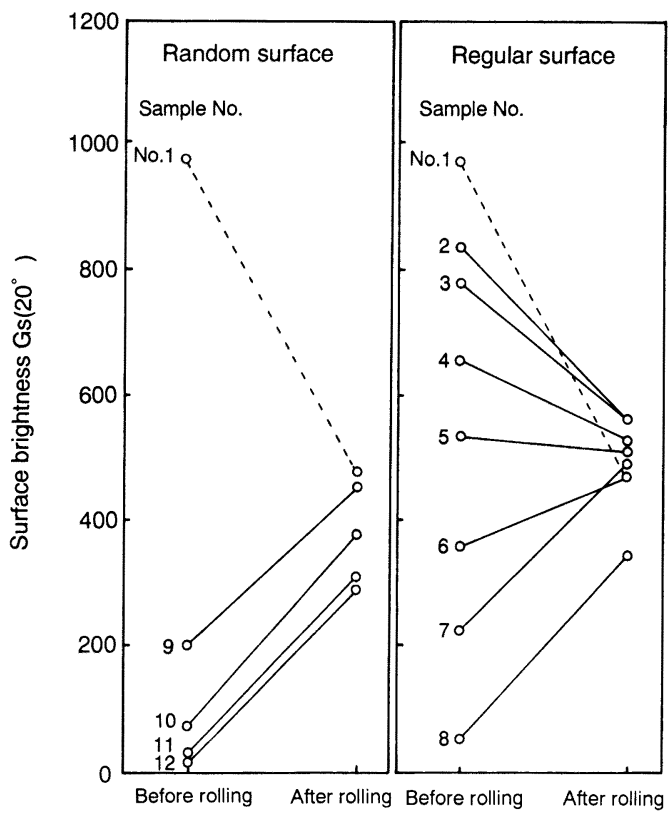

Fig. 8. Change of surface brightness of specimens having regular surface of No.2 to No.8 and random surface of No.9 to No.12 before and after rolling.

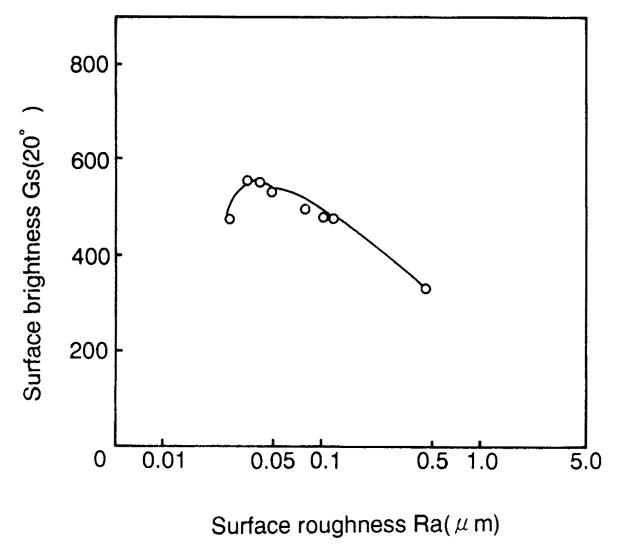

Fig. 9. Relationship between surface brightness after rolling and surface roughness before rolling for the specimens having regular surface.

いことからも定量的に理解できる1。

No. 2 8 の規則的な表面凹凸をもつ圧延試験片の場合, No. 8 の 120 エメリ紙で研磨したロールで圧延して作った
凹凸をもつ試験片以外は, No.1 の試験片の圧延後の表面光 沢よりも高い值が得られている。

Fig. 9 に規則的な凹凸をもつ圧延試験片 (No. 2 No. 8) の圧延前の表面粗さと表面光沢の関係を示す。優れた表面 光沢をるつ材料在圧延するためには，圧延前の材料表面光 沢が規則的な四凸をもっており，その表面粗さがある最適 值をもっていることが望ましいことが本システムを用いた 実験より理解できた。

\section{5. 結言}

本表面光沢推定システムを用いることにより，実機で各 パス圧延後の表面性状を実験室レベルで非常に簡単に推定 できる可能性を示した。今回の実験において，実機の各心 スでのロール表面に一致したロール表面を選べば, 実機と 一致することになろう。この推定システムを用いることに より, 新しいパススケジュールでの表面光沢の推定, 新し いロール材料を用いた場合の表面光沢の推定タラスタミル なぼの新しい圧延機を使用した場合の表面光沢の推定など を簡単に行うことができる。

おわりに, 本研究を遂行するにあたり, 実験に御協力頂 いた当時, 横浜国立大学工学部学生鈴木肇氏, 研究生野呂 和也氏に深く感謝致します。

\section{文献}

1) 小豆島明, 野吕和也, 井柳好貴, 出川浩樹 : 鉄 $飞$ 鋼, 76 (1990), p. 576

2) 小豆島明, 木原諒二, 五弓勇雄：塑性と加工, 18 (1977), p.337

3 ) 升田貞和, 八木竜一, 村田宰一: 第42回塑性加工連合講演会, (1991), p.861

4) 山本秀男, 富澤 淳, 松浦征浩, 益居 健, 松平行彦: 第42回塑 性加工連合講演会, (1991), p.873

5 ）岡本昭治, 山本 昇: 第42回塑性加工連合講演会, (1991), p.837

6）山本善康, 白石利幸, 井上 剛, 阿高松男, 中島浩樹：塑性と加 工, 33 (1992), p. 1190

7 ）剣持一仁, 鎳田征雄, 阿部英夫, 福原明彦, 小松秀夫, 坪内博之, 岸田 朗: 鉄飞銅, 78 (1992), p.1546

8 ）小豆島明, 木原毫二, 五弓勇雄：塑性 $と$ 加工, 17 (1978), p.958

9 ) 小豆島明, 北村晃一, : 昭和61年度塑性加工春期講演会講演論文 集, (1986), p.151

10）小豆島明：鉄 銅, 74 (1988), p.696

11) H. F. Atale and G. W. Rowe: Wear, 32 (1975), p.249 